\title{
PERBANDINGAN KUMPULAN CERPEN NU HARAYANG DIHARGAAN DAN RUSIAH KAOPATWELAS KARYA DARPAN (Kajian Struktural dan Étnopédagogik)
}

\author{
Ria Dwi Fartika \\ SMAN 1 Jatisari Karawang \\ Pos-el: debiriairawan@yahoo.co.id
}

\begin{abstract}
Abstrak
Penelitian ini mempunyai tujuan untuk membandingkan cerpen mana dari dua buku kumpulan cerpen karya Darpan yang lebih cocok untuk bahan pembelajaran, baik dikaji dari strukturnya, maupun etnopedagogiknya. Selain itu, peneliti mempunyai rasa penasaran akan karya pengarang orang Karawang. Metode yang digunakan dalam penelitian ini yaitu metode kualitatif, metode deskriptif, dan tekhnik yang digunakan yaitu studi pustaka. Dari hasil penelitian, $80 \%$ cerpen yang dianalisis dari dua kumpulan cerpen $\mathrm{Nu}$ Harayang Dihargaan dan Rusiah Kaopatwelas mempunyai struktur dan nilai pendidikan karakter. Hasil analisis struktur yang melingkupi tema, fakta cerita, dan sarana sastra, membuktikan bahwa tema kemanusiaan lebih dominan dari dua kumpulan cerpen. Tema kemanusiaan di sini lebih berpusat ke dalam tingginya martabat manusia, dan nilai-nilai pepatah orang tua ke anaknya. Alur yang dipakai oleh pengarang dari dua kumpulan carpon lebih dominan ke dalam alur maju dan mundur. Latar yang sering dipakai lebih menggambarkan daerah basisir, sedangkan sudut pandang lebih dominan orang ketiga tidak tersingkir. Dalam analisis nilai pendidikan karakter, lebih dominan nilai semangat kebangsaan, jujur, menghargai prestasi, religi, toleransi, disiplin, kerja keras, demokrasi, rasa ingin tahu, mandiri, peduli sosial, dan tanggung jawab. Kesimpulan dari analisis dua kumpulan cerpen menunjukkan bahwa kumpulan cerpen Nu Harayang Dihargaan dan Rusiah Kaopatwelas mempunyai struktur, dan nilai pendidikan karakter. Hasil penelitian bisa dimanfaatkan untuk alternatif bahan pembelajaran sastra di SMA, dan bisa digunakan untuk cerminan dalam kehidupan seharihari.
\end{abstract}

Kata kunci: kumpulan cerpen, bahan pembelajaran, struktural, etnopedagogik.

\section{THE COMPARISON OF SHORT STORIES COLLECTION NU HARAYANG DIHARGAAN AND RUSIAH KAOPATWELAS OF DARPAN (The Study of Stucture and Ethnopedagogy)}

\begin{abstract}
This study has the objective to compare the significance of the two books of short stories of Darpan's works. They are more suitable for learning materials, based on the perspectives of structure and ethnopedagogy. In addition, there is a curiosity considering the fact that the author is from Karawang. The methods used in this study were qualitative and descriptive methods. The study also employed literature review. Based on the results, $80 \%$ of the stories contained in both books have the structure and the values of character education. Results of the structural analysis cover themes, the facts of the stories, and the means of literature. The dominant theme of the two short stories collection is humanity. The theme of humanity is centered in the high human dignity and values of the proverbs from parents to children. The plot of the stories are a mix of forwad and backward. The backgrounds that are frequently
\end{abstract}


used mostly illustrate coastal area. The dominant viewpoint is the third person. The value of character education is more dominant to the value of the national spirit, honesty, recognizing excellence, religion, tolerance, discipline, hard work, democracy, curiosity, independence, social care, and responsibility. In conclusion, the two collections of short stories have the structure and the values of character education. They can be used as alternatives of literature learning materials in high school, as well as for reflection in daily life.

Keywords: Short Stories Collection, Teaching Material, Structure, Ethnopedagogy.

\section{PENDAHULUAN}

Karya sastra merupakan gambaran dari satu keadaan di masyarakat, di sini dapat tergambar kehidupan yang mencakup hubungan antarmasyarakat, antarmanusia, dan antarkejadian yang berlangsung dalam diri seorang manusia (tokoh). Setiap orang mempunyai cerita serta keunikan yang ada dalam dirinya masing-masing, dan setiap orang merupakan pelaku utama dalam kehidupannya, dan setiap orang juga merupakan pengarang yang membuat cerita untuk hidupnya sendiri. Hal ini bisa terwujud melewati bahasa dan bisa jadi satu kejadian unik, indah, dan menginspirasi.

Sifat sastra yang indah dan mempunyai manfaat jadi salah satu alat untuk memberi gambaran nyata dalam dunia fiksi atau rekaan. Bahasa indah yang direkayasa oleh pengarang merupakan media untuk menyampaikan ide serta pikiran pengarang yang menginterpretasikan situasi nyata dalam bentuk fiksi. Imajinasi pengarang yang digabungkan dengan pengalaman hidup bisa jadi satu karya sastra yang bermanfaat untuk orang lain, bisa jadi motivasi, atau bisa jadi hiburan untuk manusia.

Melalui bahasa, baik lisan atau tulis bisa tersampaikan maksud dan tujuan yang akan disampaikan oleh pengarang. Salah satu tujuannya yaitu sebagai alat untuk meneruskan tradisi dan revitalisasi budaya yang ada di dalam teks. Cerpen merupakan salah satu karya sastra tulis yang bukan mustahil dan lebih gampang dimengerti daripada karya-karya sastra tulis lainnya. Tarigan, (1993, hlm. 177), menyebutkan ciri-ciri cerpen yaitu: a) singkat, padat, dan intensif; b) unsur utama cerpen yaitu adegan, pelaku, dan gerak; c) bahasa dalam cerpen fokus, sugestif, dan menarik hati pembaca; d) cerpen harus mengandung interferensi pengarang mengenai konsepsinya dalam kehidupan, baik langsung dan tidak langsung; e) cerpen harus menimbulkan satu efek dalam pikiran pembaca; f) cerpen harus mempunyai pelaku utama; g) cerpen tergantung kepada satu kejadian; h) cerpen mengeluarkan satu emosi; dan i) cerpen harus mempunyai kesan yang menarik hati.

Kumpulan cerpen $\mathrm{Nu}$ Harayang Dihargaan terbagi jadi 15 cerpen, sedangkan Rusiah Kaopatwelas terbagi jadi dua bagian, yaitu bagian pertama "Si Iblis", bagian kedua "Rusiah Kaopatwelas". Bagian pertama ada 8 cerpen yang menceritakan kehidupan dan persoalan di perkampungan, bagian kedua ada 7 cerpen yang menceritakan orang kota, dan orang kota yang berasal dari kampung dan persoalanpersoalannya. Hal ini merupakan salah satu keunikan yang ada dalam cerpen ini, ada sebagian kebiasaan-kebiasaan orang Sunda yang sudah hilang dijaman sekarang, walaupun hidupnya di perkampungan, seperti menggembala kambing atau bermain di kebun bambu. Cerpen ini bisa jadi gambaran untuk anak-anak jaman sekarang untuk menunjukkan bagaimana keadaan perkampungan jaman dulu, hususnya Karawang-Bandung. Penulis kumpulan cerpen Rusiah Kaopatwelas yaitu Darpan yang berasal orang Karawang, oleh karena itu latar tempat dalam kumpulan-kumpulan cerpen ini banyak menceritakan tempattempat yang ada di Karawang seperti Cikampek. Bahasa yang digunakan termasuk mudah dimengerti oleh orang Kara- 
wang seperti Cikampek, yang kebanyakan memakai bahasa Sunda kasar atau campuran Jawa dan Betawi. Sedangkan kumpulan cerpen yang pertama kali dibuat oleh Darpan yaitu $N u$ Harayang Dihargaan, cerpen ini pernah mendapat hadiah sastra Rancagé tahun 1998. Peneliti memilih kumpulan cerpen $\mathrm{Nu}$ Harayang Dihargaan dan Rusiah Kaopatwelas karena; (1) untuk memberi gambaran untuk anak-anak jaman sekarang bagaimana keadaan alam jaman dulu di Karawang; (2) Karawang yang dulu disebut "lumbung padi" sudah tidak tergambarkan lagi, oleh karena itu diharapkan bisa memotivasi untuk menjaga alam supaya bisa indah dan bisa diturunkan ke generasi seterusnya; (3) menunjukkan bahwa orang basisir juga bisa menghasilkan karya-karya Sunda yang umumnya banyak ditulis atau diteliti oleh orang gunung; (4) membandingkan cerpen mana yang cocok dijadikan bahan pembelajaran; dan (5) bisa jadi bahan alternatif untuk bahan pembelajaran di SMA. Kumpulan cerpen $\mathrm{Nu}$ Harayang Dihargaan dan Rusiah Kaopatwelas bisa dijadikan alternatif bahan pembelajaran.

Dari membaca kumpulan cerpen ini, selain meneliti nilai pendidikan karakter, juga secara tidak langsung mengajarkan nilai moral, beberapa nilai yang ditemukan yaitu religius, jujur, toleransi, disiplin, kerja keras, kreatif, mandiri, rasa ingin tahu, cinta tanah air, menghargai prestasi, cinta damai, gemar membaca, peduli sosial jeung tanggung jawab. Sesuai dengan pendapat Noor (2011:64) dalam karya sastra biasanya menggambarkan pandangan hidup pengarang, pandangan mengenai nilai kebenaran yang ingin disampaikan kepada pembaca. Noor (2011:71) mengemukakan lima manfaat mengapresiasi sastra (anak) : (1) manpaat estetis, (2) manfaat pendidikan, (3) manfaat kepekaan batin atau sosial, (4) manfaat pengetahuan, dan (5) manfaat untuk perkembangan kepribadian. Ada beberapa peneliti yang menganalisis kumpulan cerpen Rusiah Kaopatwelas, di antaranya penelitian tentang Imbuhan
Belakang dalam Kumpulan Cerita Pendek Karya Darpan (Kajian Struktural dan Semantis) oleh Iyan Cahyani. Bedanya dengan yang dianalisis, yaitu belum ada yang menganalisis etnopedagogik dalam cerpen tersebut.

Berhubungan dengan hal yang sudah dijelaskan di atas, dan untuk menjawab rasa ingin tahu penulis, maka diteliti Perbandingan Kumpulan Cerpen $\mathrm{Nu}$ Harayang Dihargaan dan Rusiah Kaopatwelas Karya Darpan untuk Bahan Pembelajaran Sastra di SMA (Kajian Struktural-Etnopedagogik). Setiap penelitian dalam hakikatnya mempunyai tujuan. Sesuai dengan latar belakang masalah yang sudah dijelaskan di atas, maka akan dilakukan penelitian yang mempunyai tujuan 1) struktur dalam kumpulan cerpen $\mathrm{Nu}$ Harayang Dihargaan jeung Rusiah Kaopatwelas; 2) ajén étnopédagogik yang ada dalam kumpulan cerpen $\mathrm{Nu}$ Harayang Dihargaan jeung Rusiah Kaopatwelas, 3) bagaimana perbandingan struktur cerita dalam kumpulan cerpen $\mathrm{Nu}$ Harayang Dihargaan jeung Rusiah Kaopatwelas; 4) bagaimana perbandingan etnopedagogik cerita dalam kumpulan cerpen $\mathrm{Nu}$ Harayang Dihargaan jeung Rusiah Kaopatwelas; 5) bagaimana struktur cerita dan nilai etnopedagogik dalam kumpulan cerpen $\mathrm{Nu}$ Harayang Dihargaan dan Rusiah Kaopatwelas bisa dijadikan alternatif pembelajaran sastra di SMA.

\section{METODE}

Menurut Arikunto (2010, hlm. 175) desain penelitian yaitu rancangan yang menunjukkan gambaran utama mengenai hal yang dilakukan. Desain penelitian merupakan proses yang diperlukan dari rancangan penelitian sampai kepada bentuk pertanyaan yang bisa terjawab. Berdasarkan desain penelitian yang sudah dirancang, langkah awal yang dilaksanakan dalam penelitian ini yaitu menentukan masalah dan objek penelitian, dan menentukan teori serta metode penelitian, setelah itu diberi kesimpulan langkah selanjutnya menyusun 
laporan. Penelitian ini menggunakan pendekatan kualitatif dengan metode deskriptif analisis. Unsur-unsur yang akan dideskripsikan yaitu struktur dan nilai pendidikan karakter dalam kumpulan cerpen Nu Harayang Dihargaan dan Rusiah Kaopatwelas karya Darpan. Sumber data dari dua buku kumpulan cerpen ini adalah 30 cerpen yang dari masing-masing bukunya yang terdapat 15 cerpen. Sedangkan sampel yang diambil adalah $25 \%$ dari sumber data yaitu menjadi 8 carpen yang dianalisis.

\section{HASIL DAN PEMBAHASAN}

Istilah cerpen sebenarnya berasal dari bahasa Inggris yaitu short story. Arti dari cerpen itu sendiri yaitu fiksi pendek yang selesai dibaca dalam sekali duduk. Cerita pendek mempunyai satu arti, satu krisis, dan satu efek kepada pembaca. Sumardjo (1980, hlm. 21). Faturohman (1983, 56-59) menyatakan bahwa dilihat dari tema dan gaya basanya, cerita pendek yang berkembang di sastra Sunda bisa dibagi menjadi empat golongan, yaitu cerita pendek biasa, cerita pendek absurd, cerita pendek liris, dan cerita pendek humoris. 1) cerita pendek biasa yaitu cerita pendek yang ditulis dengan menggunakan aturan-aturan yang lumrah. Seperti tema yang menggambarkan keadaan yang sering terjadi dalam kehidupan sehari-hari, begitu juga dengan pelaku yang memerankan, yaitu tokoh-tokoh yang biasa memegang peran dalam kehidupan sehari-hari, 2) cerita pendek absurd yaitu cerita pendek yang unsur-unsur ceritanya tidak biasa dalam realitas, sebaliknya dari cerita pendek biasa, dalam cerita pendek absurd struktur ceritanya tidak terlalu jadi masalah, bahkan ada cerita pendek yang tidak tentu alurnya, 3) yang membedakan cerita pendek liris dengan cerita pendek biasa yaitu dalam gaya basanya. Dalam cerita pendek liris bahasa yang dipakai sangat cermat dalam pemilihannya, bahkan lebih diutamakan pemilihan bahasa yang mempermanis dan murwakanti, 4) cerita pendek humoris yaitu cerita pendek yang mengandung unsur humor atau lucu. Biasanya unsur humor ini berasal dari deskripsi pengarang, atau dari percakapan tokoh-tokohnya.

Dalam sastra Sunda ada pengarang spesialis cerita pendek humoris, yaitu Ahmad Bakri. Sedangkan pengarang angkatan sebelumnya yaitu GS dan Mohamad Ambri. Berdasarkan pembagian cerpen di atas, bisa terlihat bahwa kumpulan cerpen $\mathrm{Nu}$ Harayang Dihargaan dan Rusiah Kaopatwelas termasuk dalam golongan cerita pendek biasa, karena tema dan gaya bahasa yang digunakan sangat realitas dalam kehidupan sehari-hari, hal ini terlihat dari nama-nama tempat, kebiasaan, dan istilah-istilah bahasa yang sering digunakan oleh orang Karawang. Stanton (2012, hlm 45) menyebutkan bahwa unsur karya fiksi bisa dilihat dari wujud (a) tema, (b) fakta cerita, dan (c) sarana sastra. Stanton (2012, hlm. 36) menyebutkan bahwa tema yaitu aspek cerita yang sejajar dengan 'makna' dalam pengalaman manusia, sesuatu yang menjadikan suatu pengalaman begitu diingat.

Ada banyak cerita yang menggambarkan dan menelaah kejadian atau emosi yang dialami manusia seperti cinta, derita, rasa takut, kedewasaan, keyakinan, pengkhianatan manusia terhadap diri sendiri, disilusi, atau bahkan usia tua. Sedangkan fakta cerita terbagi ke dalam beberapa point, yaitu a) karakter b) alur, dan c) latar. Stanton (2012: 22) mengatakan bahwa karakter, alur, dan latar merupakan faktafakta cerita. Elemen-elemen ini berfungsi sebagai catatan kejadian imajinatif dari sebuah cerita. Jika dirangkum menjadi satu, semua elemen ini dinamakan 'struktur faktual' atau 'tingkatan faktual' cerita. Secara umum, alur merupakan rangkaian peristiwa-peristiwa dalam sebuah cerita. Istilah alur biasanya terbatas pada peristiwa-peristiwa yang terhubung secara kausal saja. Peristiwa kausal merupakan peristiwa yang menyebabkan atau menjadi dampak dari berbagai peristiwa lain dan tidak dapat diabaikan karena akan berpe- 
ngaruh pada keseluruhan karya. Semakin sedikit karakter dalam sebuah cerita, semakin rekat dan padat pula alur yang mengalir di dalamnya.

Alur merupakan tulang punggung cerita. Berbeda dengan elemen-elemen lain, alur dapat membuktikan dirinya sendiri meskipun jarang diulas panjang lebar dalam sebuah analisis. Sama halnya dengan elemen-elemen lain, alur memiliki hukumhukum sendiri, alur hendaknya memiliki bagian awal, tengah, dan akhir yang nyata, meyakinkan dan logis, dapat menciptakan bermacam kejutan, dan memunculkan sekaligus mengakhiri ketegangan-ketegangan. Karakter merujuk pada percampuran dari berbagai kepentingan, keinginan, emosi, dan prinsip moral dari individuindividu.

Sedangkan latar adalah lingkungan yang melingkupi sebuah peristiwa dalam cerita, semesta yang berinteraksi dengan peristiwa-peristiwa yang sedang berlangsung.

Yang terakhir yaitu sarana sastra yang melingkupi a) judul, b) sudut pandang, c) gaya bahasa, dan d) simbol. Stanton (2012: 46) mengatakan bahwa sarana sastra dapat diartikan sebagai metode (pengarang) memilih dan menyusun detail cerita agar tercapai pola-pola yang bermakna. a) Judul merupakan satu hal yang penting dalam suatu cerita. Judul bisa memberi gambaran mengenai isi cerita, walaupun judul tidak selamanya sesuai dengan isi cerita. Judul ada kalanya berwujud simbol falsafah, walaupun sebenarnya judul merupakan hak preogatif pangarang untuk menandakan karangannya; b) sudut pandang pada dasarnya merupakan visi pengarang, artinya sudut pandang yang diambil oleh pengarang untuk melihat satu kejadian cerita. Berdasarkan tujuannya Stanton (2012: 53) membagi empat sudut pandang, yaitu: 1) pada 'orang pertama-utama', sang karakter utama bercerita dengan kata-katanya sendiri, 2) pada 'orang pertama sampingan', cerita dituturkan oleh satu karakter bukan utama (sampingan), 3) pada 'orang ketiga- terbatas', pengarang mengacu pada semua karakter dan memposisikannya sebagai orang ketiga tetapi hanya menggambarkan apa yang dilihat, didengar, dan dipikirkan oleh satu orang karakter "saya", 4) pada 'orang ketiga tidak-terbatas', pengarang mengacu pada setiap karakter dan memposisikannya sebagai orang ketiga. Pengarang juga dapat membuat beberapa karakter melihat, mendengar, atau berpikir ketika tidak ada satu karakter pun hadir; c) gaya bahasa adalah cara pengarang dalam menggunakan bahasa; dan d) simbol berwujud rincian konkrit dan faktual, juga mempunyai kemampuan untuk memunculkan gagasan serta emosi dalam pikiran pembaca. Etnopedagogik yang digunakan untuk menganalisis dua kumpulan cerpen ini yaitu lebih kepada 18 pendidikan karakter seperti religius, jujur, toleransi, disiplin, kerja keras, kreatif, mandiri, rasa ingin tahu, cinta tanah air, menghargai prestasi, cinta damai, gemar membaca, peduli sosial, dan tanggung jawab.

\section{Sinopsis}

Diceritakan bahwa ada seorang anak bernama Ani yang baru pulang dari sekolahnya, karena Ani sering pulang terlalu sore, maka ibunya pun memarahinya. Ani mengatakan pada ibunya bahwa dia baru pulang dari rumah gurunya (Pak Agus) untuk membantu pekerjaan rumah sang guru seperti mencuci piring dan memasak. Mendengar hal itu terang saja ibunya langsung marah, karena selama ini Ani tidak pernah membantu pekerjaan ibunya sendiri karena beralasan ada Ma Acem yang selalu membantu ibunya. Setiap hari hal ini selalu terulang, hingga suatu hari Ani tidak berani bermain di rumah sang guru lagi karena kali ini ibunya sangat marah sekali.

Setiap pulang sekolah Ani selalu mengurung diri di kamar karena merasa marah pada ibunya. Pada suatu hari keluar perkataan yang membuat ibunya menjadi tertegun. Sambil menangis Ani bertanya pada ibunya, bahwa apa sebenarnya yang 
membuat ibunya sangat membenci Pak Agus, ibunya hanya berkata bahwa dia tidak suka Ani selalu membantu Pak Agus sedangkan pekerjaan di rumahnya sendiripun diabaikan. Pak Agus sendiri mempunyai sikap baik hati, baik ketika di sekolah ataupun di luar sekolah. Ketika mengetahui Ani sudah tidak mempunyai seorang Ayah, maka kasih sayangnya kepada Ani melebihi murid-murid lainnya, sampai Ani dijuluki "anak emas" oleh teman-temannya sendiri.

Karena Ani sudah jarang berkunjung ke rumah Pak Agus lagi, maka kali ini Pak Aguslah yang sekarang berkunjung ke rumah Ani. Ketika Pak Agus datang pertama kali ke rumahnya, rasa marah terlihat dari raut wajah ibunya. Tapi tentu saja hal ini tidak dikatakan pada Pak Agus. Perasan berbeda justru ditunjukkan Ani yang merasa bahagia Pak Agus berkunjung ke rumahnya, Ani pun mulai rajin membantu pekerjaan ibunya di rumah. Esoknya Pak Agus datang lagi, raut wajah heran pun tergambar diwajah ibunya, Ani mengatakan bahwa kemarin ibunya ingin mencari orang yang bisa membetulkan kandang ayam di rumahnya, oleh karena itu Ani mengajak Pak Agus untuk membetulkan Kandang ayam tersebut. Tentu saja bukan ini yang dimaksudkan ibunya.

Dari hari ke hari intensitas kunjungan Pak Agus semakin sering, bahkan pernah sekali waktu Pak Agus pulang malam hari. Pada suatu hari ibunya menyuruh Ani mengantarkan pepes ikan ke rumah $\mathrm{Pa}$ Agus, Ani yang kaget bukan main pun loncat-loncat kegirangan, karena dalam benaknya, akhirnya ibunya menyukai Pak Agus. Seperempat jam kemudian dengan wajah kecewa Ani pun kembali sambil menenteng pepes ikan yang dibawa tadi. Ibunya pun menjadi terkejut dan menanyakan apa yang terjadi, tapi Ani hanya diam dengan wajah yang seperti ingin menangis. Dengan terbata-bata Ani mengatakan bahwa di rumah Pak Agus sedang ada anak dan istrinya, dengan tenang ibunya berusaha mengalihkan bahwa mungkin saja orang yang ada di rumah Pak Agus bukan anak dan istrinya, tapi dengan tegas Ani membenarkan hal itu karena ini pun perkataan Pak Agus sendiri. Sambil menangis, pepes ikan yang tadinya akan diberikan kepada Pak Agus pun dilempar ke dalam tungku, dan memukul-mukul kandang ayam yang sudah dibetulkan oleh Pak Agus.

Tangisan Ani yang semakin keras membuat ibunya menjadi sedih. Ibunya langsung memeluk Ani, dan dalam pelukan ibunya Ani mengatakan bahwa dia ingin ayahnya. Alasan selama ini Ani sering berkunjung ke rumah Pak Agus adalah karena mendambakan sosok ayah yang sudah tidak ada lagi di dunia ini.

Secara struktural didapat bahwa:

a. Tema

Tema dari judul cerpen "Asih dina Lauk Pais" di atas yaitu kemanusiaan. Kemanusiaan dalam penelitian ini lebih kepada cinta antara orang tua dan anak. Tokoh utama yang bernama Ani jauh dilubuk hatiny, sangatlah merindukan ayahnya, sehingga setiap pulang sekolah Ani selalu menyempatkan utuk bermain kerumah gurunya (Pa Agus) yang mempunyai sifat baik hati, sabar, dan penyayang. Dibalik sifat ibunya yang selalu marah-marah karena Ani selalu bermain ke rumah Pa Aguspun, bukan karena semata-mata ingin dibantu pekerjaan dirumah saja, tapi karena hawatir dan tahu apa yang ada dibenak Ani yang mendambakan sosok seorang ayah.

b. Pelaku

Pelaku utama dalam cerpen ini yaitu Ani dan ibunya, keduanya saling membantu atas jalannya cerita ini, tapi tentu saja Ani lebih dominan. Selain itu ada juga pelaku kedua yaitu Pak Agus dan dua pelaku tambahan Pak Ulis yang menyukai ibunya Ani, dan Ma Acem yang selalu membantu pekerjaan di rumah Ani. 
c. Latar

Latar yang tergambar dari cerpen ini yaitu latar tempat, waktu dan sosial. Ada tiga latar tempat yaitu rumah, sekolah, dan dapur. Satu latar waktu dan dua latar sosial. Latar tempat rumah paling sering dipakai dalam cerpen ini, salah satunya adalah ketika Ani baru pulang dar sekolah, latar tempat sekolah ketika hari senin pada saat upacara bendera kepala sekolah mengabarkan ada guru baru yaitu Pak Agus, dan latar tempat dapur ketika Ani dan ibunya terlibat percakapan. Sedangkan latar waktu adalah ketika sore hari pada saat ibunya menyuruh Ani untuk memberikan pepes ikan. Dua latar sosial yang muncul dalam cerpen ini adalah guru dan kepala sekolah yang kedua-duanya menunjukkan status sosial atau jabatan seseorang di dalam lingkup sekolah.

d. Alur

Alur yang digunakan pengarang dalam cerpen ini adalah alur maju dan mundur. Alur mundur terjadi pada saat pengarang menceritakan tokoh Ani yang sudak tidak bermain ke rumah Pa Agus lagi, dan memilih berdiam diri di kamar.

e. Judul

Jika dilihat secara keseluruhan, antara judul dan isi cerita kurang sesuai, tetapi tidak mengurangi makna yang terkandung didalamnya. Pada mulanya pembaca akan bertanya-tanya apa maksudnya "Asih dina Pais Lauk" karena dari awal tidak ada kejadian tentang pepes ikan, tapi hal ini baru terjawab di akhir cerita sekaligus klimaks dari cerita.

\section{f. Sudut pandang}

Sudut pandang yang digunakan pengarang dalam cerpen ini adalah orang ketiga tidak terbatas, disini pengarang mengacu pada karakter Ani dan memposisikannya sebagai orang ketiga. Pada penelitian ini pengarang juga membuat tokoh Ani dapat mendengar, melihat, atau berpikir.

g. Gaya bahasa
Gaya bahasa yang digunakan dalam cerpen ini sangat mudah dimengerti, sehingga pembacapun dapat mengerti apa yang tergambar dalam cerita ini.

h. Simbol

Ada tiga simbol dalam cerita ini, yaitu guru, kepala sekolah, dan anak emas. Guru dan kepala sekolah melambangkan status sosial seseorang di dunia pendidikan, dan anak emas adalah simbol yang diberikan kepada anak yang mendapat perhatian lebih, dll.

Analisis pendidikan karakter yang tergambar dalam cerpen 'Asih dina Lauk Pais" yaitu rasa ingin tahu, peduli sosial, dan semangat kebangsaan. Ada dua belas nilai pendidikan karakter yang tergambar dalam cerpen ini, rasa ingin tahu lebih didominasi oleh ibunya Ani, Ibu Ani selalu khawatir kepada putrinya yang selalu pulang sore hari, apalagi Ani adalah anak perempuan satu-satunya di keluarga. Selain ibunya, rasa ingin tahu juga dirasakan oleh Ani yang heran atas sikap ibunya yang sangat terlihat sekali membenci Pak Agus. Nilai peduli sosial tergambar ketika Pak Agus selaku guru baru ditempatkan di perumahan guru, bekas Pak Edi (guru sebelumnya), di sini murid-murid saling membantu kepindahan Pak Agus, dari mulai anak lelaki yang mencat tembok, menghampelas tembok, dan membereskan buku. Anak perempuan pun diceritakan ikut membersihkan debu, menyapu, dan memasak untuk gurunya. Hal ini sangat jelas terlihat rasa peduli sosial yang ditunjukkan oleh anak-anak yang terbilang masih kecil (kelas 4). Dan yang terakhir semangat kebangsaan, semangat kebangsaan tergambar ketika digambarkan upacara bendera. Anak-anak yang bersemangat sangat menunjukkan rasa senangnya di sekolah. Hal ini tentu saja bertolak belakang dengan sekolah-sekolah di daerah kota yang minim dengan lahan untuk melakukan upacara bendera. Hal ini bisa jadi gambaran untuk anak-anak sekarang tentang rasa nasionalisme dan semangat sebagai orang Indonesia. 
Cerpen-cerpen yang dianalisis adalah "Mulang, Layung Geus Ririakan, Si Ato Miara Jago, Dongéng Jurig, Budak nu Teu Balik, Rusiah Kaopatwelas, dan Asih dina Lauk Pais". Cerpen "Mulang" mempunyai tema kemanusiaan, hal ini berdasarkan nilai-nilai kemanusiaan yang ada di dalamnya. Profesi Dedeh (pelaku utama) dalam cerpen Mulang yaitu seorang pelacur, hal ini yang menghilangkan hati nurani masyarakat di sekelilingnya dalam berbuat baik kepadanya, Dedeh dianggap hina dan bukan manusia, walupun tokoh Dedeh sebenarnya hanya korban temannya sendiri.

Ada dua cerpen yang mempunyai tema rumah tangga, yaitu "Si Ato Miara Jago" dan "Rusiah Kaopatwelas" kedua cerpen ini berkisar seputar rumah tangga. Warnasih merupakan tokoh utama dalam cerpen " $\mathrm{Si}$ Ato Miara Jago" dan suaminya sangat suka mengadu ayam, bahkan setiap hari yang diurusnya adalah ayam. Selain itu Warnasih mempunyai seorang anak bernama Ato, Ato sama seperti ayahnya suka sekali dengan ayam, tapi Ato berbeda, dia tidak memelihara bukan untuk jadi ajang aduan. Pusat permasalahan dalam cerita ini yaitu ketika suaminya tersangkut masalah karena kasus pemukulan dengan tetangganya, maka Sardi (nama suami Warnasih) kabur dan tidak tahu kemana rimbanya. Akhirnya Warnasihlah tulang punggung keluarga. Suatu hari saat sedang memikirkan kebutuhan mereka kedepannya, datanglah Juna (teman suaminya) yang sedang mencari ayam yang bagus untuk dijadikan aduan, dan ketika melihat ayam peliharaan Ato, tertariklah Juna untuk membelinya. Rasa bingung dan gelisah menghampiri Warnasih ketika Juna menawar dengan harga yang tinggi. Disisi lain Warnasih membutuhkan uang itu untuk menyambung hidupnya, sedangkan disisi lain Warnasih tidak tega untuk menjual ayam kesayangan Ato. Tapi hal ini terlupakan ketika Juna memberikan uang untuk membeli ayam itu. Sore harinya Ato pulang ke rumah dan mencari-cari ayamnya, ketika tahu ayamnya dijual, maka me- ledaklah kemarahan Ato. Warnasih secepat mungkin menuju rumah Juna untuk membeli ayam itu lagi. Tetapi hal ini justru menjadi petaka untuk Warnasih, karena selama ini Juna tertarik dengan Warnasih. Juna akhirnya mendapat kesempatan untuk mendapatkan Warnasih. Rasa bimbang melanda Warnasih, sehingga dia tidak sadar dengan apa yang diperbuat Juna. Dan tanpa sengaja Warnasih membunuh Juna. Sambil menangis dan menenteng ayam Warnasih pulang ke rumahnya, ayam yang ditenteng diberikan ke Ato, dan seketika itu tangisannya pun berhenti seakan-akan tidak terjadi apa-apa. Setelah itu Warnasih masuk ke kamar dan menangis sejadi-jadinya. Tidak lama setelah itu terdengar suara pentungan dan kabar bahwa Juna dibunuh. Walaupun disini suaminya dikisahkan tidak ada, tapi tentu saja ini termasuk dalam permasalahn rumah tangga yang akhirnya menjerumuskan Warnasih dan tanggung jawab nafkah yang seharusnya tugas suami malah menjadi tanggungan Warnasih. Sedangkan dalam cerpen "Rusiah Kaopatwelas" permasalahan rumah tangga terletak ketika tokoh Neneng yang dikisahkan oleh (Aku) menderita penyakit kanker dan divonis mati. Disini Neneng mengadu kepada sahabatnya (tokoh Aku), Neneng tetap bersikeras untuk menyimpan rahasia ini kepada suami dan anaknya, dan kebimbangan melanda (tokoh Aku) antara harus menyimpan dan mengatakannya. Disisi lain itu bukan haknya, tapi disisi lain juga dia tidak bisa menyimpan rahasia ini sendiri.

Tema cinta ada pada cerpen "Asih dina Pais Lauk" seperti yang sudah digambarkan di atas dan cerpen "Layung Geus Ririakan" tema cinta pada kedua cerpen ini lebih kepada rasa cinta dan nasihat orang tua kepada anak.

Sedangkan tema sosial ada pada cerpen "Dongeng Jurig dan Budak nu Teu Balik" tema sosial terletak pada hubungan kedua cerpen ini dengan masyarakat dilingkungan sosialnya. Galur maju ada disemua judul cerpen yang dianalisis, sedangkan 
galur mundur hanya tidak ada didalam cerpen "Layung Geus Ririakan”.

Latar dari semua cerpen yang dianalisis hamper semua mengisahkan daerah pedesaan yang indah dan identik dengan pesawahan, hanya dicerpen "Budak nu Teu Balik" saja yang terdapat latar tempat perkotaan. Sedangkan dari segi judul ada tiga judul cerpen yang sesuai dengan judul yaitu "Mulang, Budak nu Teu Balik, dan Rusiah Kaopatwelas", tentu saja sebenarnya ini adalah hak pengarang, karena sebenarnya seorang pengarang yang berhak atas karyanya.

Dari sudut pandang, semuanya memakai sudut pandang 'orang ketiga-terbatas' hanya pada cerpen 'Rusiah Kaopatwelas' saja yang menggunakan tokoh "aku" yang artinya menggunakan sudung pandang 'orang pertama-utama'.

Gaya basa yang digunakan pengarang dalam cerpen-cerpen diatas sebenarnya sangat mudah dimengerti, tetapi ada beberapa yang memang terdengar kasar karena merujuk pada kisah para pelakunya, seperti dalam cerpen "Mulang" yang memang menceritakan tokoh utama yang berprofesi seorang pelacur. Selain itu pengarang juga menyisipkan beberapa peribahasa didalam cerpen untuk menambah kesan didalamnya.

Dari pendidikan karakter, setiap cerpen memiliki pendidikan karakter, walaupun tidak semuanya memiliki 18 nilai pendidikan karakter. Pendidikan karakter lebih banyak di "rasa ingin tahu dan tanggung jawab".

\section{SIMPULAN}

Berdasarkan hasil analisis struktur dari dua kumpulan cerpen $\mathrm{Nu}$ Harayang Dihargaan dan Rusiah Kaopatwelas bisa disimpulkan dalam beberapa poin seperti di bawah ini:

1. Tema lebih dominan ke dalam tema kemanusiaan dan sosial. Hal ini dikarenakan cerpen-cerpen karya Darpan lebih dominan ke dalam realitas-realitas yang ada dalam kehidupan bermasyarakat. Pengarang dapat membawa pembaca supaya mengalami hal yang diceritakan atau dibayangkan sebagaimana kejadiannya. Proses kritik pada kejadian-kejadian kemanusiaan dan kehidupan sosial di daerah Tatar Sunda digambarkan melalui konflik-konflik dalam dua tema yang dominan.

2. Alur yang dipakai Darpan dalam dua kumpulan cerpen ini banyak yang menggunakan alur campuran dan alur maju, oleh karena itu, cerita yang digambarkanpun lebih bervariatif.

3. Para pelaku yang ada dalam cerpencerpen karya Darpan dijelaskan berdasarkan pada norma masyarakat Sunda yang memberi sugesti positif kepada pembaca. Gambaran para pelaku yang berwatak baik bisa dijadikan contoh untuk pembaca, sedangkan ada juga para pelaku yang menjadi cerminan karena watak atau sifat yang kurang baik.

4. Latar-latar yang ada dalam cerpencerpen karya Darpan lebih banyak menggunakan latar tempat untuk menghidupkan cerita agar terasa nyata. Latar waktu dan sosial dipakai untuk menambahkan keadaan sosial masyarakat.

Sedangkan untuk etnopedagogik yang lebih menjurus ke pendidikan karakter digunakan untuk menganalisis dua kumpulan cerpen ini. Pendidikan karakter yang lebih dominan yaitu Tanggung Jawab dan Rasa Ingin Tahu. Pendidikan Tanggung Jawab menggambarkan mengenai falsafah hidup, yaitu dimana setiap orang harus berani menghadapi segala hal yang sudah ditentukan dan menerima semua keputusan yang telah diambil oleh diri sendiri. Pendidikan Rasa Ingin Tahu merupakan gambaran dari perasaan alami manusia yang mempunyai akal untuk meningkatkan kemampuan dirinya sendiri.

\section{PUSTAKA RUJUKAN}

Arikunto, Suharsimi. (2010). Prosedur Penelitian Satu Pendekatan Praktisi. Jakarta: PT. Rineka Cipta. 
Noor, M Rohinah. (2011). Pendidikan Karakter Berbasis Sastra). Jogjakarta : Ar-Ruz Media.

Faturohman, Taufik. (1983). Ulikan Sastra: Pangajaraan Sastra Sunda Pikeun Murid Smtp. Bandung. Djatnika.

Stanton, Robet. (2012). Teori Fiksi Robert Stanton. Yogyakarta: Pustaka Pelajar.

Sumardjo, Jakob. (1980). Seluk Beluk Cerita Pendek. Bandung: Mitra Srangenge.
Tarigan, Henry Guntur. (1993). PrinsipPrinsip Dasar Sastra. Bandung: Rizqy Press.

\section{UCAPAN TERIMA KASIH}

Kepada para pembimbing tesis yang telah membantu penelitian ini penulis mengucapkan terima kasih. Tidak luput pula ucapan terima kasih dan penghargaan setinggi-tingginya penulis sampaikan kepada penyunting Jurnal Lokabasa yang telah memuat tulisan ini. 